\title{
Prognosis of Clinically Insignificant Residual Renal Stone Fragments Following Therapy with Minimally Invasive Techniques
}

\author{
Minimal İnvaziv Tekniklerle Tedavi Sonrası Klinik Önemsiz Rezidü Böbrek Tașı Parçalarının Akıbeti
}

\section{Murat Bağcıoğlu', Serkan Özcan², Mert Ali Karadağ'1, Tolga Karakan³ ${ }^{3}$ Hasan Turğut", Aslan Demir¹, Ömer Faruk Yağ|ı}

${ }^{1}$ Department of Urology, Kafkas University School of Medicine, Kars, Turkey; ${ }^{2}$ Department of Urology, Artvin State Hospital, Artvin, Turkey; ${ }^{3}$ Department of Urology, Ankara Training and Research Hospital, Ankara, Turkey; ${ }^{4}$ Department of Urology, Akcaabat Halkal Baba State Hospital, Trabzon, Turkey

\begin{abstract}
Following the treatment with minimally invasive surgical techniques, residual renal stone fragments may make a negative impact on the life quality of patients by causing symptoms. The term of clinically insignificant residual stone fragments is used to describe the asymptomatic and non-obstructive posttreatment residual fragments remained in the kidney, which are smaller than $4 \mathrm{~mm}$ (or $5 \mathrm{~mm}$ ), and associated with sterile urine. However, the stone fragments may cause the formation of a new stone acting as a nidus. The accumulated evidence suggests that there is no significant difference between treatment and follow up in short term, however the stone disease recurs in $20 \%$ of the cases in long term. Thus, close followup of the patients with clinically insignificant residual fragments is mandotary. Lifestyle changes and medical therapy may be helpful in the management and prevention of new stone formation.
\end{abstract}

Key words: kidney stones; lithotripsy; review; ureteroscopic surgery

\section{ÖZET}

Minimal invaziv cerrahi teknikler ile tedavi sonrasında kalan rezidü böbrek tașı parçaları, belirtilere neden olarak hastaların hayat kalitesi üzerine olumsuz etki yapabilirler. Klinik önemsiz rezidü terimi, tedavi sonrasında böbrekte kalan, $4 \mathrm{~mm}$ (bazen $5 \mathrm{~mm}$ ) ve daha küçük olan, asemptomatik, obstrüksiyona neden olmayan ve idrarın steril olduğu durumdaki taș parçaları için kullanılır. Bununla birlikte, klinik önemsiz rezidü için önemli bir nokta da nidus șeklinde yeni taș olușumuna neden olabilmesidir. Biriken veriler kısa dönemde tedavi etmekle, takip arasında fark olmadığını söylese de, uzun dönemde \%20 olguda yeni taș hastalığı gelișir. Bunun için klinik önemsiz rezidü tașı olan hastalarda yakın takip zorunludur. Yașam tarzı değișikliği ve medikal tedavi sağaltım ve yeni taș olușumunun önlenmesinde yardımcı olabilir.

Anahtar kelimeler: böbrek tașlarl; lithotripsi; derleme; ureteroskopik cerrahi

Yard. Doç. Dr. Murat Bağcıoğlu, Kafkas Üniversitesi Tip Fakültesi, Sağlık Uygulama ve Arasttrma Hastanesi, Üroloji Anabilim Dal, Kars, Türkiye Tel.05062020066Email.dr.muratbagcioglu@hotmail.com

Received: 11.12.2014 - Accepted: 10.02.2015

\section{Introduction}

Symptomatic urinary stones failing to pass sponteneosly are managed with various treatment options. Appropriate individual treatment choice depends on various facts. Stone burden, localization, size and type of stone, presence of urinary tract infection or congenital anatomical abnormalities may be effective. Extracorporeal shock wave lithotripsy (ESWL), ureterorenoscopy (URS), retrograde intrarenal surgery (RIRS), percutaneous nephrolithotomy (PCNL), laparoscopic and open surgeries may be options.

The residual stone fragments after open surgical procedures were accepted as failure or insufficient treatment. Although open surgical procedures have been replaced by minimally invasive surgical techniques by many surgeons, stone remnants may persist in the urinary system and the remained stone fragments after minimally invasive surgery stone are not cleared immediately. Thus, the term of clinically insignificant residual fragments (CIRFs) is used to describe such posttreatment residual fragments, which are smaller than $4 \mathrm{~mm}$ (or $5 \mathrm{~mm}$ ), asymptomatic, non-obstructive and associated with sterile urine. ${ }^{1,2}$ The residual stone fragments may interfere with the quality of life of patients and the residual fragments can lead to stone formation acting as a nidus.

\section{Definition and Outcomes of Clinically Insignificant Residual Fragments}

The success of an open stone surgery was defined as removing all of the stones. Remained stone fragments 
were accepred as the failure of the treatment. However, current treatment modalities changed the treatment goals. With minimally invasive procedures, the success of the intervention depended on the the size of the remaining stone fragments and fragmentation rates. Thus, stone fragments smaller than $4 \mathrm{~mm}$ in size were defined as "clinically insignificant".

Regrowth of the residual stones has been detected with higher incidences after ESWL and minimally invasive procedures $^{3-5}$. Residual fragments following ESWL or PNL lead to high rates of symptomatic episodes, as well as high rates of repeat intervention ${ }^{6}$. The incidence and/or rates of recurrent disease vary with the type of stone, size of the fragment and the type of the procedure.

\section{CIRFs after Shock Wave Lithotripsy (SWL)}

Streem and co-workers determined the clinical significance of small, asymptomatic, non-infectious stone fragments after SWL. ${ }^{7}$ The authors followed up 160 patients for a mean period of 23 months. Asymptomatic patients with $4 \mathrm{~mm}$ or smaller calcium oxalate and calcium phosphate stone fragments after SWL were included in the study. Stone-free status or a decreased, stable or increased amount of residual stone occurred in 38 (23.8\%), 26 (16.3\%), 67 (41.9\%) and 29 (18.1\%) of the 160 patients, respectively. The probability of a stone-free, stone-free or decreased status, or stone-free decreased or stable status was $0.36,0.53$, and 0.80 , respectively at fifth year after SWL. Ninety one patients (56.9\%) were asymptomatic while $69(43.1 \%)$ were symptomatic or required intervention during a mean period of 26 months (1.6-85.4 months) after SWL (probability estimated at 0.71 at 5 years). The authors stated that patients with small non-infectious stone fragments could be followed expectantly after SWL, however a significant number of patients had symptomatic episodes or would require intervention within two years. They concluded that the application of the term CIRFs after SWL might not be appropriate.

Zanetti and co-workers reviewed the therapeutic implications and long-term outcome of asymptomatic patients with dust and residual fragments (less than $4 \mathrm{~mm}$ ) at third month after SWL ${ }^{3}$. A total of 129 patients were re-examined with radiographic studies, renal ultrasonography and urine culture at 12 th month, and 95 were also evaluated at 24 th month. The patients were defined as stone-free or with persistent lithiasis or with regrowth stone. At the end of the 12-months follow up period, 60 patients (46.5\%) were stone-free and $56(43.5 \%)$ still had residual fragments or dust. There was no significant difference between the stone free rates, size and localization of the stones or fragments at three months and 12 months; however stones or fragments larger than $10 \mathrm{~mm}$ enlarged more frequently ( 11 of 40 patients, $27.5 \%$, versus 2 of $89,2.2 \%$; P $1 / 40.001)$ in 13 patients (10\%). The probability of eliminating residual lithiasis at 12 th month was significantly higher in patients with dust than in those with residual fragments ( 42 of 79 patients, $58 \%$, versus 18 of $50,36 \% ; \mathrm{P}=0.026)$. They concluded that in short term follow up period, the patients with fragments do not require systematic retreatment; however if symptoms persisted or stones recurred they might be followed and retreated in long-term.

Buchholz et al. investigated the fate of residual fragments, less than $5 \mathrm{~mm}$, after SWL over a long period. ${ }^{8}$ The study aimed to determine the rate and time of the sponteneous pass of the fragments. They also aimed to clarify regrowth, recurrence and their role in clinical outcome. The records of 266 patients containing a mean follow up period of 387 days were analyzed. Fifty five patients $(21 \%)$ with residual fragments $<5 \mathrm{~mm}$ in diameter were detected after SWL. Sex, age, medical history, and SWL retreatment rates were not significantly different between the patients with or without residual fragments. After a mean follow up period of 2.5 years, $12.7 \%$ of the patients with residual stones had not passed the fragments spontaneously, but all of them were in clinically stable status and the fragments were located in the proximal ureter and the lower calices. Stone regrowth was observed in only $2 \%$ of the patients with residual fragments and no stone recurrences were observed within the follow-up period. The authors concluded that more invasive procedures to reach stone free status were not essential.

In a study by Khaitan et al. 81 patients were followed after SWL to clarify the fate of the CIRFs for a mean period of 15 months (6-60 months). In 18 patients, the fragments passed spontaneously during the followup, 13 patients were in clinically stable status, and 44 patients develeoped cninically significant complications. Thus, percutaneous nephrolithotomy in three, ureteroscopic stone removal in four and repeat SWL in 16 patients were needed. Conservative analgesic treatment was sufficent in the remaining 21 patients. CIRFs in the caliceal location mostly became symptomatic and $53 \%$ of the CIRFs located in the pelvis passed 
spontaneously. In addition clinical symprtoms were related with the stone burden and number of stone fragments. Moreover, the clearance rate was highest during the first six months. Finally, the rate of complications correlated with the duration of follow up, the number and size of residual fragments. The authors stated that patients with residual stones required close follow up and timely adjuvant therapy after SWL. For spontaneous passage, the pelvic location was a favorable factor. Although the clearance rate of CIRFs with repeated SWL was lower than the operative techniques, most patients improved with this modality. ${ }^{9}$

Rassweiler and co-workers, in their review analyzed the data obtained from 14000 patients. $^{2}$ They compared the data with long-term results of two centers in Germany by comparing the stone localization, stone size, observation time and the anatomical kidney situation. They found that the stone passage was continuous during a 24 months follow up period after SWL. New generation equipments and technology in SWL have increased the CIRFs percentage. The authors stated that $25 \%, 55 \%$ and $20 \%$ patients with CIRFs would be stone-free or remain clinically insignificant or clinically significant, respectively, during follow up. If there was not any clinical symptom, secondary interventions would be considered as over-treatment. Only 4-25\% of their patients required an additional intervention which was mostly a repeat SWL.

\section{CIRFs after Ureteroscopy}

Rebuck et al. investigated the fate of postureteroscopic renal stone fragments less than $4 \mathrm{~mm}^{10}$. The aim of ureteroscopy is to fragment stones, and remove larger fragments with basket catheter and allow the small pieces to pass spontaneously. From May 2001 to July 2008, patients treated with ureteroscopy and holmium laser lithotripsy by a single surgeon were included in the study. Fifty one of 330 ureteroscopies met inclusion criteria. Patients with residual renal fragments measuring $4 \mathrm{~mm}$ on initial postoperative CT and at least one additional follow up CT were included. Spontaneous passage of the fragments, regrowth of the fragments, and stone events like emergency visits, hospitalization and additional interventions were recorded. The mean follow-up duration was 18.9 months (1.6 years). During follow up, among 46 patients, nine (19.6\%) experienced a stone event, $10(21.7 \%)$ passed their fragments spontaneously, and the remaining 27 (58.7\%) were in clinically stable status and asymptomatic. The mean fragment size was similar as $2.7,3.3,3.5$, and 3.0 $\mathrm{mm}$ at mean follow-up durations of $2.8,10.2,16.8$, and 33.0 months, respectively. The authors concluded that approximately one in five (or 19.6\%) of the patients with postureteroscopic CIRFs would experience a stone event over the following 1.6 years. The remaining patients will either became stone-free via spontaneous passage or retained asymptomatic stable-sized fragments.

\section{CIRFs after Percutaneous Nephrolithotomy (PCNL)}

Altunrende and associates analyzed the data of 430 patients who underwent PCNL during a three-year period and defined CIRFs as asymptomatic, noninfectious stone fragments less than $4 \mathrm{~mm}^{11}$. Stone-free rate for their study was $74.5 \%$, and CIRFs were detected in $22 \%$ of cases by kidney-ureter-bladder (KUB) graphy three months after surgery. Thirty eight patients with CIRFs after PCNL were included in the study for a mean period of $28.4 \pm 5.3$ months follow-up and $26.3 \%$ of patients had a stone event that needed medical treatment during follow-up, while others were asymptomatic. An increase in the size of the fragments was detected by radiologic assessment in $21.1 \%$ of patients, while the sizes were stable or decreased in $71.1 \%$ of cases. Three (7.9\%) patients had passed their stones spontaneously. Metabolic evaluation revealed metabolic abnormalities in 10 (26.3\%) patients. Magnesium ammonium phosphate (struvite) was detected by stone analysis in three of eight patients with increased sizes of residual fragments. In addition, only one of these eight patients had hypocitraturia and one of eight had hypercalciuria as a metabolic abnormality. They concluded that CIRFs after PCNL had progression in medium-term follow-up (most common in first two years). Increase in fragment size was common in patients with struvite stones, and presence of risk factors in 24-hour urine metabolic analysis did not seem to predict growth.

Ganpule and Desai analyzed the outcomes of residual fragments after PCNL and they aimed to determine the factors predicting spontaneous passage ${ }^{12}$. The authors analyzed the outcomes of 2469 patients after PCNL between January 2000 to January 2008. Residual stone fragments were detected in $187(7.57 \%)$ patients. The mean size of fragments was $38.6 \pm 52 \mathrm{~mm}^{2}$ and the most common localization of the fragments was lower calyx (57.7\%). Eighty-four patients (approximately half of the patients) passed their stones spontaneously at a mean follow-up period of 24 months. $65.4 \%$ of 
these stones passed in three months. Size of the fragments were less than $25 \mathrm{~mm}^{2}$ and pelvic location had the best chance of clearance. The authors stated that surgeon experience, size of residue, presentation time of residue, presence of double-j stent, preoperative nephrostomy drainage, a history of intervention, metabolic abnormalities such as hypercalcuria and hyperuraecemia were significant in predicting the fate of residuel fragments after PCNL.

\section{CIRFs in Children}

The definition is adapted from adult studies, thus the fate of CIRFs is not known well in children. Afshar et al. studied residual stone fragments ( $5 \mathrm{~mm}$ or less) following SWL in children. The records of 83 patients (39 boys and 44 girls) and 88 renal units with urinary stone disease after SWL were analyzed. The median age, average stone burden and follow up period were 7 years, $14 \mathrm{~mm}$ and 46 months, respectively. Forty renal units (46\%) became stone-free after first session of SWL and 18 renal units (20\%) had residual fragments. Twelve of the remaining 30 (34\%) units rendered stone free after additional interventions including SWL and surgical procedures. Residual fragments were detected in remaining eight renal units. A total of 26 renal units with residual fragments were included in the study. Regrowth of residual fragments, calculi recurrence in stone-free cases and symptomatic episodes were recorded. Eighteen renal units (69\%) had residual fragments growth or symptoms, and eight $(31 \%)$ patients had no stone growth or symptoms. The growth of residual fragments was associated with metabolic disorder presence (odds ratio 11.4). The authors concluded that residual fragments after SWL increased the chance of adverse clinical outcome and these fragments were clinically significant in children. Patients with residual fragments, especially those with metabolic disorders, required close follow up ${ }^{13}$.

Dincel et al. assessed CIRFs in children after SWL, PCNL and retrograde intrarenal surgery (RIRS). Eighty five children were followed up for a mean period of 22 months. Spontaneous passage of the fragments, regrowth of the fragments, and stone events like emergency visits, hospitalization and additional interventions were recorded. Only 22 children (25.8\%) had passsed the residual fragments spontaneously. Thirty four patients had (40\%) renal colic, heamaturia or urinary tract infection, and $20(23.5 \%)$ patients required medical treatment. Regrowth of the residual fragments were detected in 18 children (21.2\%) and secondary intervention was required in 25 children (29.4\%). They concluded that, the term of CIRFs was not appropriate for postoperative residual fragments in children ${ }^{14}$.

\section{Management of Residual Stones}

The possible complications of residual stones are related to dislocation of fragments with obstruction and symptoms, persistent urinary tract infection and the risk of develeoping new stones from the nidus ${ }^{5,15-18}$.

Patients with residual fragments require close followup to monitor the course of stone disease. Adjunctive treatment with tamsulosin may improve the clearance and the stone-free rate after SWL and ureterorenos$\operatorname{copy}^{19}$. Treatment includes high diuresis and mechanical percussion for small fragments located in tle lower calix to facilitate the stone clearence ${ }^{20}$. A diet containing high intake of fluids, vegetables and fruits; lower consumption of protein and salt and a balanced intake of fats, calcium and carbohydrates constitutes an efficacious tratment and prevention approach.

Regular exercise, appropriate body weight, and reducing stress are also useful preventive actions. ${ }^{21}$ To prevent the complications, identification of biochemical risk factors is particularly indicated in patients with residual fragments or stones ${ }^{19}$. Since the metabolic disturbances underlying stone formation persist after procedures, recurrence of the disease is inextricably linked to the institution of medical therapy (eg, thiazide diuretic and low salt diet for hypercalciuria, and potassium citrate for hypocitraturia, allopurinol or potassium citrate for hyperuricosuria). It was shown that medical therapy is effective in preventing stone growth and recurrence ${ }^{22}$.

\section{References}

1. Delvecchio FC, Preminger GM. Management of residual stones. Urol Clin North Am 2000;27:347-54.

2. Rassweiler JJ, Renner C, Chaussy C, et al. Treatment of renal stones by extracorporeal shockwave lithotripsy: an update. Eur Urol 2001;39:187-99.

3. Zanetti G, Seveso M, Montanari E, et al. Renal stone fragments following shock wave lithotripsy. J Urol 1997;158:352-5.

4. Streem SB. Long-term incidence and risk factors for recurrent stones following percutaneous nephrostolithotomy or percutaneous nephrostolithotomy/extracorporeal shock wave lithotripsy for infection related calculi. J Urol 1995;153:584-7. 
5. Osman MM, Alfano Y, Kamp S, et al 5-year-follow-up of patients with clinically insignificant residual fragments after extracorporeal shockwave lithotripsy. Eur Urol 2005;47:860-4.

6. Raman JD, Bagrodia A, Gupta A, et al. Natural history of residual fragments following percutaneous nephrostolithotomy. J Urol 2009; 181:1163-8.

7. Streem SB, Yost A, Mascha E. Clinical implications of clinically insignificant store fragments after extracorporeal shock wave lithotripsy. J Urol 1996;155:1186-90.

8. Buchholz NP, Meier-Padel S, Rutishauser G. Minor residual fragments after extracorporeal shockwave lithotripsy: spontaneous clearance or risk factor for recurrent stone formation? J Endourol 1997;11:227-32.

9. Khaitan A, Gupta NP, Hemal AK, et al. Post-ESWL, clinically insignificant residual stones: reality or myth? Urology 2002;59:20-4.

10. Rebuck DA, Macejko A, Bhalani V, et al. The natural history of renal stone fragments following ureteroscopy. Urology 2011;77:564-8.

11. Altunrende F, Tefekli A, Stein RJ, et al. Clinically insignificant residual fragments after percutaneous nephrolithotomy: medium-term follow-up. J Endourol 2011;25:941-5.

12. Ganpule A, Desai M. Fate of residual stones after percutaneous nephrolithotomy: a critical analysis. J Endourol 2009;23:399-403.

13. Afshar K, McLorie G, Papanikolaou F, et al. Outcome of small residual stone fragments following shock wave lithotripsy in children. J Urol 2004;172:1600-3.
14. Dincel N, Resorlu B, Unsal A, et al. Are small residual stone fragments really insignificant in children? J Pediatr Surg 2013;48:840-4.

15. Balaji KC, Menon M. Mechanism of stone formation. Urol Clin North Am 1997;24:1-11.

16. El-Nahas AR, El-Assmy AM, Madbouly K, et al. Predictors of clinical significance of residual fragments after extracorporeal shockwave lithotripsy for renal stones. J Endourol 2006;20:870-4.

17. Buchholz NP, Meier-Padel S, Rutishauser G. Minor residual fragments after extracorporeal shockwave lithotripsy: spontaneous clearance or risk factor for recurrent stone formation? J Endourol 1997;11:227-32.

18. Shigeta M, Kasaoka Y, Yasumoto $H$, et al. Fate of residual fragments after successful extracorporeal shock wave lithotripsy. Int J Urol 1999;6:169-72.

19. Türk C, Knoll T, Petrik A, et al. EAU Guidelines on Urolithiasis. Update March 2014.

20. Chiong E, Hwee ST, Kay LM, et al. Randomized controlled study of mechanical percussion, diuresis, and inversion therapy to assist passage of lower pole renal calculi after shock wave lithotripsy. Urology 2005;65:1070-4.

21. Meschi T, Nouvenne A, Borghi L. Lifestyle recommendations to reduce the risk of kidney stones. Urol Clin North Am 2011;38:313-20.

22. Preminger GM, Peterson R, Peters PC, et al. The current role of medical treatment of nephrolithiasis: the impact of improved techniques of stone removal. J Urol 1985; 134:6-10. 